\title{
INHALT
}

\section{EINFÜHRUNG 7}

DIE VERFASSUNG DER LAKEDAIMONIER

Einleitung I5

Text und Übersetzung $\quad 22 / 23$

AGESILAOS

Einleitung 7I

Text und Übersetzung $\quad 78 / 79$

HIERON ODER ÜBER DIE TYRANNIS

Einleitung I45

Text und Übersetzung $152 / 153$

POROI ODER ÜBER EINKÜNFTE

Einleitung 205

Text und Übersetzung $2 \mathrm{I} 2 / 2 \mathrm{I} 3$

ANHANG

Zur Textgestaltung 249

Erläuterungen 250

Glossar 266

Chronologie 268

Literaturhinweise 270

Verzeichnis der Eigennamen 275 
